\title{
Cytotoxic Activity of Alpinumisoflavone from Erythrina poeppigiana (Leguminosae) Against Colon Cancer (WiDr), Cervical Cancer (Hela), and Hepatoma Cancer $\left(\mathrm{HepG}_{2}\right)$ Cells
}

\author{
Tati Herlina*, Nayla Haraswati, Riza Apriani, Vicki Nishinarizki, Shabarni Gaffar, Unang Supratman \\ Department of Chemistry, Faculty of Mathematics and Natural Sciences, Universitas Padjadjaran, Sumedang, Indonesia
}

\section{ARTICLE INFO}

Article history:

Received July 19, 2018

Received in revised form September 18, 2018

Accepted February 7, 2019

KEYWORDS:

Erythrina poeppigiana,

alpinumisoflavone,

cytotoxic activity

\begin{abstract}
Cancer is the second cause of death after cardiovascular diseases in the world. Anticancer prevention used can cause undesirable things. Flavonoids are secondary metabolites derived from natural products that are useful for anticancer treatment. This study was performed to observe the cytotoxic activity of alpinumisoflavone from Erythrina poeppigiana, toward cervical cancer (Hela), colon cancer (WiDr), and hepatoma cancer $\left(\mathrm{HepG}_{2}\right)$ cells. The cytotoxic activity of alpinumisoflavone was tested using (3-[4,5-dimethylthiazol-2-yl]-2,5 diphenyltetrazolium bromide) assay. The percentage of cell mortality was calculated and the $\mathrm{IC}_{50}$ was calculated using probit analysis. The result shown that alpinumisoflavone has antiproliferative effect to colon cancer (WiDr), cervical cancer (Hela), and hepatoma cancer $\left(\mathrm{HepG}_{2}\right)$ cells with the value of $\mathrm{IC}_{50}$ are 5.63, 7.18, and $18.08 \mu \mathrm{g} / \mathrm{ml}$, respectively. Based on the value of $\mathrm{IC}_{50}$ alpinumisoflavone is very cytotoxic to colon cancer WiDr cell.
\end{abstract}

\section{Introduction}

Cancer is a very common problem with many ways of healing and prevention therapy. Chemotherapy is one of the many ways to prevent cancer, but it can cause a patient's health to decrease. Therefore, there is a focus on using alternative treatments and safe therapies against cancer. Medicinal plant species are already being used to treat or prevent development of cancer (Greenwell and Rahman 2015).

Medicinal plants contain secondary metabolites with potential anticancer activities have been reported. The species Erythrina poeppigiana which is a family of Leguminosae and famous medicinal plants is used as a traditional medicine for anthelmintic, cancer, malaria, and inflammatory processes. Extracts of the leaves, stem bark, and roots of E. poeppigiana are known to contain secondary metabolites such as alkaloids and flavonoids (Herlina et al. 2018).

Previously, phytochemical analysis of E. poeppigiana has known the presence of erythrina alkaloids and isoflavonoids. Five isoflavonoids, erypogeins A, B, C, D, and $E$ have been isolated from the roots of $E$. poeppigiana and eleven isoflavones were isolated from the stem bark of E. poeppigiana (Tanaka et al. 2001, 2002; Herlina et al. 2017). Purified flavonoids have also shown anticancer

\footnotetext{
* Corresponding Author

E-mail Address: tati.herlina@unpad.ac.id
}

activities against other human cancers including; hepatoma (Hep-G2), cervical carcinoma (Hela), and breast cancer (MCF-7) (Greenwell and Rahman 2015). The affinity of isoflavonoids for the estrogen receptors ER $\alpha$ and ER $\beta$ was evaluated using a receptor binding assay (Djiogue et al. 2009).

The cytotoxic activity of erypogein $\mathrm{D}$ from the stem bark of E. poeppigiana showed the highest activity $\left(\mathrm{IC}_{50}\right.$ $30.12 \mathrm{M}$ ) against breast cancer MCF-7 cell compared to cervical cancer HeLa and ovarian cancer SKOV-3 cells in vitro by using MTS assay method, this indicates that erypogein $\mathrm{D}$ belongs to the category of moderate cytotoxic activity (Herlina et al. 2017). Alpinumisoflavone compound (Figure 1) isolated from the stem bark of $E$. poeppigiana that has never been studied for cytotoxic activity. Thus, in this study, we reported the cytotoxic activity of alpinumisoflavone against cervical cancer (Hela), colon cancer (WiDr), and hepatoma cancer $\left(\mathrm{HepG}_{2}\right)$ cells.

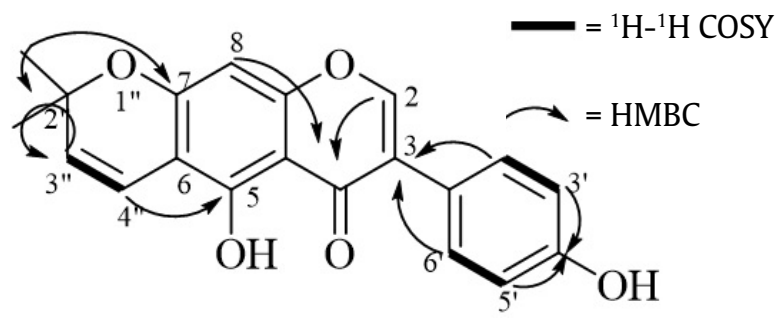

Figure 1. The correlation ${ }^{1} \mathrm{H}-{ }^{1} \mathrm{H}$ COSY and $\mathrm{HMBC}$ 


\section{Materials and Methods}

\subsection{Extraction and Isolation}

The alpinumisoflavone was isolated from the stem bark of $E$. poeppigiana in the Organic Chemistry Laboratory, Universitas Padjadjaran, Indonesia. The dried powder of stem bark $(2.4 \mathrm{~kg})$ was extracted with methanol at room temperature for @ 3 x 24 h. The evaporated methanol extract ( $155.9 \mathrm{~g}$ ) was then partitioned successively with $n$-hexane and ethyl acetate, to yield viscous concentrated of $n$-hexane $(24.0 \mathrm{~g})$ and ethyl acetate $(30.0 \mathrm{~g})$. The ethyl acetate extract $(30.0 \mathrm{~g}$ ) was fractionated by column chromatography on silica gel using a gradient $n$-hexane-ethyl acetate-methanol to give seven fractions $(A-G)$. Fraction $C(8.0 \mathrm{~g})$ eluted with gradient of $n$-hexane/ethyl acetate (from 9:1 to 100:0) was subjected to RF-18 column chromatography eluting with a gradient of methanol/water (from 8:2 to $100: 0$ ) to obtain compound 1 ( $24 \mathrm{mg}$ ).

\subsection{Cell Culture (WiDr, HeLa, and HepG ${ }_{2}$ ) Cells}

The HeLa, WiDr, and $\mathrm{HepG}_{2}$ cells were used to determine the cytotoxic activity of alpinumisoflavone. The HeLa (ATCC, CCL-2), WiDr (ATCC, HTB-77), and $\mathrm{HepG}_{2}$ (ATCC, HTB-22) cells were provided by the Faculty of Medicine Research Center, Universitas Gajah Mada, Yogyakarta. The WiDr and HeLa cell lines were maintained in DMEM (Gibco, 1195-065), 10\% fetal bovine serum (FBS) (Gibco, 10270), and 1\% Abam (Gibco, 15240-062), while $\mathrm{HepG}_{2}$ cell lines were maintained in McCoy's BA (Gibco, 16600-082), and added the same reagents for HeLa cell lines. HeLa, WiDr, and $\mathrm{HepG}_{2}$ cells were secured under $37^{\circ} \mathrm{C}, 5 \% \mathrm{CO}_{2}$ atmospheric, and 95\% humidity. During an incubation time of 24 hours, calculation of viable number of cells with the addition of Trypan blue staining and analyzed using haemocytometer (Widowati et al. 2013).

\subsection{Cytotoxic Assay}

Cytotoxic activity of alpinumisoflavone on the treated cells were determined using the (3-[4, 5-dimethylthiazol-2-yl]-2,5 diphenyltetrazolium bromide) MTT colorimetric assay modified method. The treated cells culture $(90 \mu \mathrm{l})$ of HeLa, WiDr, and $\mathrm{HepG}_{2}$ cells at density of 104 cells/well were distributed in 96-wells plates. Ten microlitres of the alpinumisoflavone at 100.0, 50.0, 25.0, 12.5, 6.25, and $3.25(\mu \mathrm{g} / \mathrm{ml})$ was added to each well. Culture medium alone was served as negative control. The plate was then incubated for $24 \mathrm{~h}$ at $37^{\circ} \mathrm{C}$ in a $5 \% \mathrm{CO}_{2}$. The mixture was further added with $20 \mu \mathrm{l}$ of using MTT, incubated for 4 hours at $37^{\circ} \mathrm{C}$ in $5 \%$ of $\mathrm{CO}_{2}$. The absorbance was read at $490 \mathrm{~nm}$ wavelength (7). The cell growth inhibition was determined with the equation (2). \% of cell growth inhibition $=(\mathrm{OD}$ of control cell-OD of treated cell $) /($ OD of control cell) x $100 \%$. Inhibitory concentration $\left(\mathrm{IC}_{50}\right)$ were determined using probit analysis. The $\mathrm{IC}_{50}$ values was obtained from average of three times independent experiments (Widowati et al. 2013).

\section{Results}

\subsection{Analytical Data of Compound 1}

Compound 1 as yellow crystal. Mp: $207-210^{\circ} \mathrm{C}$; IR (KBr):3422, 2977, 1659, 1463, 1060, $800 \mathrm{~cm}-1$; UV/Vis $\lambda \max (\mathrm{MeOH}) \mathrm{nm}(\log \varepsilon): 282$ (4.27), 213 (4.53); HRTOFMS ES- spectrum showed [M+H]- 335.0877, calcd $\mathrm{m} / \mathrm{z}$ 335.0861. The ${ }^{1} \mathrm{H}$ NMR (600 MHz) and ${ }^{13} \mathrm{C}$ NMR (150 MHz) spectroscopic data in $\mathrm{CDCl}_{3}$ (Table 1 ).

Table $1 .{ }^{1} \mathrm{H}$ and ${ }^{13} \mathrm{C}$ NMR spectroscopic data compound 1 and alpinumisolfavone in $\mathrm{CDCl}_{3}$

\begin{tabular}{|c|c|c|c|c|}
\hline \multirow{2}{*}{ Pos. } & \multicolumn{2}{|c|}{ Compound 1} & \multicolumn{2}{|c|}{ Alpinumisoflavone } \\
\hline & $\delta \mathrm{C}^{\mathrm{a}}$ (mult) & $\delta \mathrm{H}^{\mathrm{b}}$ (Int., mult.. $\left.J=\mathrm{Hz}\right)$ & $\delta \mathrm{C}^{\mathrm{c}}($ mult $)$ & $\delta \mathrm{H}^{\mathrm{d}}$ (Int., mult.. $\left.J=\mathrm{Hz}\right)$ \\
\hline 2 & $152.7(\mathrm{~d})$ & $7.81(1 \mathrm{H}, \mathrm{s})$ & $153.0(\mathrm{~d})$ & $7.78(1 \mathrm{H}, \mathrm{s})$ \\
\hline 3 & $123.7(\mathrm{~s})$ & - & & - \\
\hline 4 & $181.1(\mathrm{~s})$ & - & $181.4(\mathrm{~s})$ & - \\
\hline $4 a$ & $106.2(\mathrm{~s})$ & - & $106.5(\mathrm{~s})$ & - \\
\hline 5 & $156.9(\mathrm{~s})$ & $13.01(1 \mathrm{H}, \mathrm{s})$ & $157.2(\mathrm{~s})$ & $13.07(1 \mathrm{H}, \mathrm{s})$ \\
\hline 6 & $105.7(\mathrm{~s})$ & - & $106.0(\mathrm{~s})$ & - \\
\hline 7 & $159.7(\mathrm{~s})$ & - & $160.0(\mathrm{~s})$ & - \\
\hline 8 & $95.0(\mathrm{~d})$ & $6.33(1 \mathrm{H}, \mathrm{s})$ & $95.3(d)$ & $6.30(1 \mathrm{H}, \mathrm{s})$ \\
\hline $8 a$ & $157.4(\mathrm{~s})$ & - & $156.5(\mathrm{~s})$ & - \\
\hline $1^{\prime}$ & $123.0(\mathrm{~s})$ & - & $124.0(\mathrm{~s})$ & - \\
\hline $2^{\prime}$ & $130.4(\mathrm{~d})$ & $7.34(1 \mathrm{H}, \mathrm{d}, 7.8)$ & 130.7 (d) & $7.31(1 \mathrm{H}, \mathrm{d}, 8.1)$ \\
\hline $3^{\prime}$ & $115.7(\mathrm{~d})$ & $6.84(1 \mathrm{H}, \mathrm{d}, 7.8)$ & 116.1 (d) & $6.82(1 \mathrm{H}, \mathrm{d}, 8.1)$ \\
\hline $4^{\prime}$ & $156.1(\mathrm{~s})$ & - & $157.7(\mathrm{~s})$ & - \\
\hline $5^{\prime}$ & $115.7(\mathrm{~d})$ & $6.84(1 \mathrm{H}, \mathrm{d}, 7.8)$ & $116.1(\mathrm{~d})$ & $6.82(1 \mathrm{H}, \mathrm{d}, 8.1)$ \\
\hline $6^{\prime}$ & $130.4(\mathrm{~d})$ & $7.34(1 \mathrm{H}, \mathrm{d}, 7.8)$ & 130.7 (d) & $7.31(1 \mathrm{H}, \mathrm{d}, 8.1)$ \\
\hline $2 "$ & 78.2 (s) & - & $78.5(\mathrm{~s})$ & - \\
\hline $3 "$ & $128.3(\mathrm{~d})$ & $5.62(1 \mathrm{H}, \mathrm{d}, 9.6)$ & $128.6(\mathrm{~d})$ & $5.59(1 \mathrm{H}, \mathrm{d}, 10)$ \\
\hline $4 "$ & $115.5(\mathrm{~d})$ & $6.71(1 \mathrm{H}, \mathrm{d}, 9.6)$ & $115.9(\mathrm{~d})$ & $6.69(1 \mathrm{H}, \mathrm{d}, 10)$ \\
\hline $2 "-\mathrm{CH}_{3}$ & $28.4(\mathrm{~d})$ & $1.46(6 \mathrm{H}, \mathrm{s})$ & $28.7(\mathrm{~d})$ & $1.44(6 \mathrm{H}, \mathrm{s})$ \\
\hline
\end{tabular}




\subsection{Cytotoxic Activity Compound 1 Against Colon Cancer (WiDr), Cervical Cancer (Hela), and Hepatoma Cancer $\left(\mathrm{HepG}_{2}\right.$ ) Cells}

The MTT method was used to determined of cytotoxic activity against WiDr, HeLa, and $\mathrm{HepG}_{2}$ cells. The results of cytotoxic activities are summarized in Table 2.

\subsection{Morphological Appearance of WiDr, HeLa, and $\mathrm{HepG}_{2}$ Cells}

The morphological appearance of WiDr, HeLa, and $\mathrm{HepG}_{2}$ cells treated with compound 1 was showed in the Figure 2, 3, and 4.

\section{Discussion}

\subsection{Characteristics of Compound 1}

The UV absorption maxima of compound 1 in methanol were absorved at a peak 1 and 2 (287 and $205 \mathrm{~nm}$ ), which is characteristic of the carbonyl bound

Table 2. The $\mathrm{IC}_{50}$ value of WiDr, HeLa, and $\mathrm{HepG}_{2}$ cells

\begin{tabular}{cc}
\hline Cells & $\mathrm{IC}_{50}(\mu \mathrm{g} / \mathrm{ml})$ \\
\hline $\mathrm{WiDr}$ & 5.63 \\
$\mathrm{HeLa}$ & 7.18 \\
$\mathrm{HepG}_{2}$ & 18.08 \\
\hline
\end{tabular}

to a benzene group. The compound 1 was added $\mathrm{AlCl}_{3}$ reactants showed bathochromic and hypochromic shift at a peak I and II (294 and $210 \mathrm{~nm}$ ), indicating the formation of a compound $\mathrm{AlCl}_{3}$ complex between the hydroxyl and ketone groups, compound 1 is characteristic of isoflavone. Its IR spectrum showed absorption characteristic of hydroxyl and ketone aromatic $\left(3422,1659\right.$, and $\left.1640 \mathrm{~cm}^{-1}\right)$.

The ${ }^{1} \mathrm{H}$ NMR spectrum of compound 1 showed the presence of a signals typical of an isoflavone nucleus having a pyran ring. The ${ }^{1} \mathrm{H}$ NMR spectrum revealed a pair of doublets $(J=9.6 \mathrm{~Hz})$ centered on $\delta 5.62$ and 6.71 and sharp singlets six proton intensities at 46 1.46. The ${ }^{1} \mathrm{H}$ NMR spectrum also displayed a pair of doublets $(J=7.8 \mathrm{~Hz})$, each integrating for two protons, at $\delta 6.84$ and 7.34 , which were assigned to the $\mathrm{H}-3^{\prime}$ and $\mathrm{H}^{-} 5^{\prime}$, and $\mathrm{H}-\mathrm{2}^{\prime}$ and $\mathrm{H}-\mathrm{6}^{\prime}$ of the para-disubstituted aromatic nucleus. The relatively upfield resonance $(\delta$ 6.84) of $\mathrm{H}-3^{\prime}$ and $\mathrm{H}^{-5}{ }^{\prime}$ suggested the presence of an oxygenated substituent at C -4 '. The proton signal of hydroxyl group showed the presence of a broad singlet at $\delta 6.33(1 \mathrm{H})$, due to a hydroxyl group proton. These were assigned to a 2,2-dimethylchromene ring system. The characteristic C-2 proton of the isoflavone skeleton was evident as a singlet at $\delta 7.81$ $(1 \mathrm{H})$.
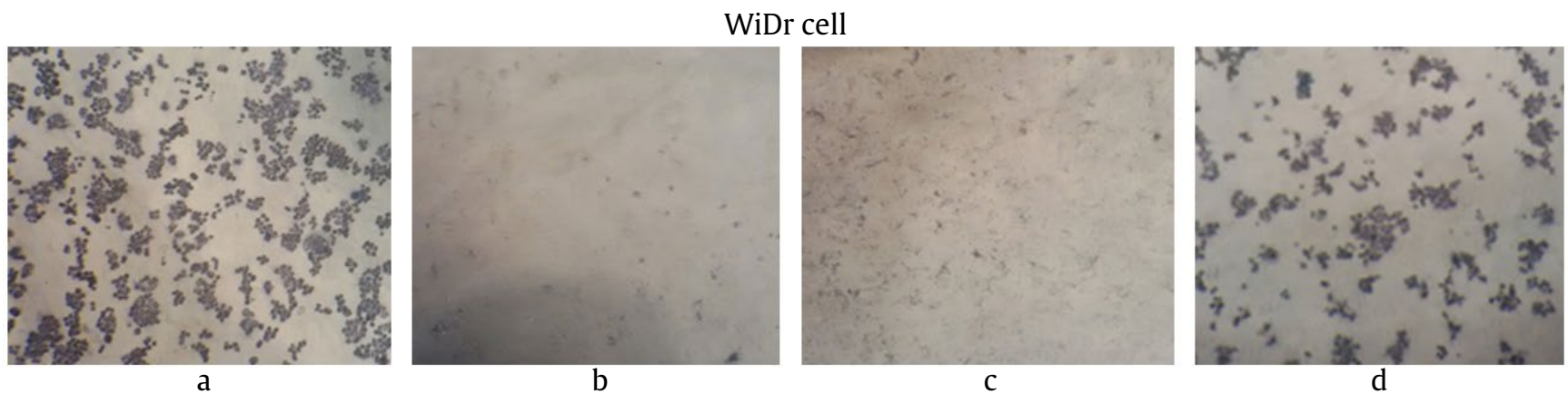

Figure 2. Morphological appearance of WiDr cells with treatment of compound 1: (a) control, (b) 50.0, (c) 12.5, and (d) $3.25 \mu \mathrm{g} / \mathrm{ml}$. Scale bar: $40 \mathrm{x}$
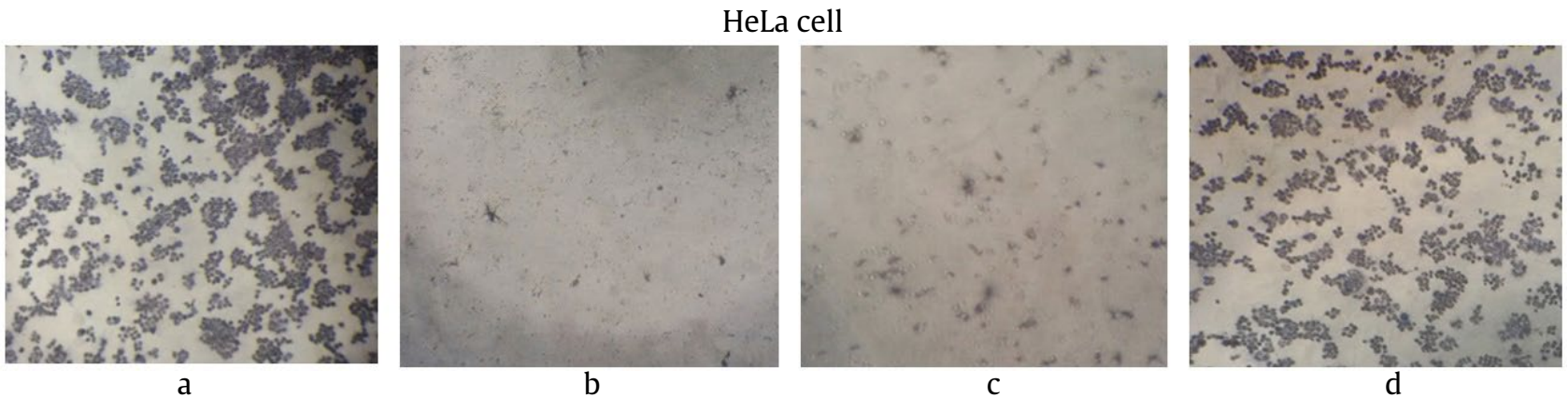

Figure 3. Morphological appearance of HeLa cells with treatment of compound 1: (a) control, (b) 50.0, (c) 12.5, and (d) $1.56 \mu \mathrm{g} / \mathrm{ml}$. Scale bar: $40 \mathrm{x}$ 

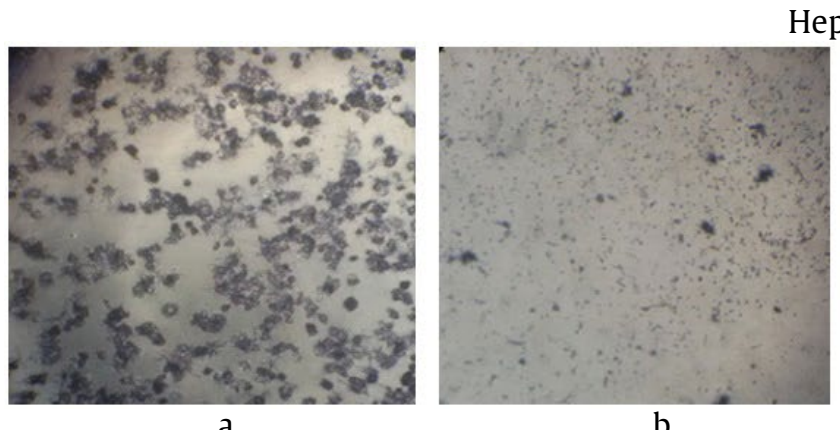

$\mathrm{HepG}_{2}$ cell
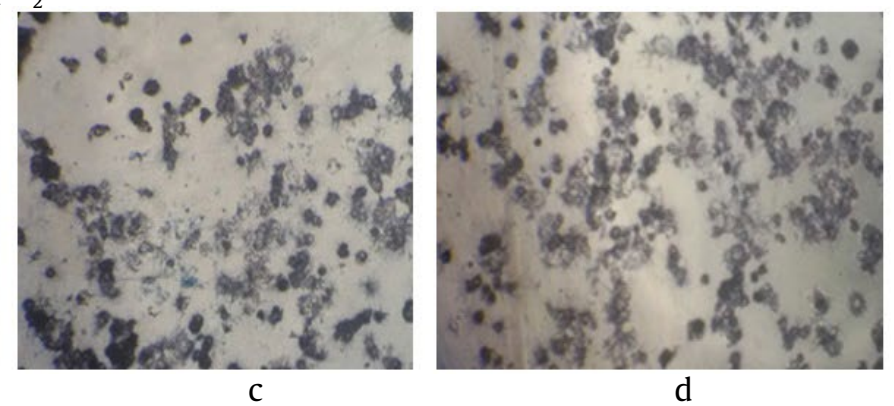

Figure 4. Morphological appearance of $\mathrm{HepG}_{2}$ cells with treatment of compound 1: (a) control, (b) 50.0, (c) 12.5, and (d) $1.56 \mu \mathrm{g} / \mathrm{ml}$. Scale bar: 40x

The HMQC spectrum of compound 1 showed signal of $\mathrm{H}-2$ (7.81) was bounded to an oxygenated carbon of C-2 (152.7), this was showed of compound 1 is characteristic of isoflavone. The ${ }^{1} \mathrm{H}-{ }^{1} \mathrm{H}$ COSY spectrum of compound 1 showed the presence of a cross peak between $\mathrm{H}-2$ ' (7.34) and H-3' (6.84), H-5' (6.84) and H-6' (7.34) indicated that the protons are ortho position, and the crossing peaks between H-3" (5.62) and H-4" (4.71). The HMBC spectrum of compound 1 showed correlation of signal H-3' (6.84) with C-4' (156.1) and H-5' (6.84) with C-4' (156.1), indicated of hydroxyl group position at C-4'. The correlation of signal H-4" (6.71) with C-5 (156.9), indicated of hydroxyl group position at $\mathrm{C}-5$. The correlation of signal proton (1.46) with C-7 (78.2) and C-2" showed of 2,2-dimethylpyran ring position (Figure 4). The ${ }^{1} \mathrm{H}$ and ${ }^{13} \mathrm{C}$ NMR spectroscopic data compound 1 and alpinumisoflavone in $\mathrm{CDCl}_{3}$ (Table 1 ). On the basis of the above spectral data and by comparison of these values with those reported for alpinumisoflavone, $\mathrm{C}_{20} \mathrm{H}_{16} \mathrm{O}_{5}$. Alpinumisoflavone with another name is 5-hydroxy-7-(p-hydroxyphenyl)2,2-dimethyl-2H-6Hbenzo-[1,2-b:5,4-b]dipyran-6one (Hussaini et al. 2011).

\subsection{Cytotoxic Activity of Alpinumisoflavone}

As shown in Table 2, alpinumisoflavone had the the lowest $\mathrm{IC}_{50}$ in colon cancer WiDr cell $(5.63 \mu \mathrm{g} /$ $\mathrm{ml}$ ) which indicated highest cytoxicity compared to cervical cancer cell (Hela) and hepatoma cancer cell $\left(\mathrm{HepG}_{2}\right)$. Alpinumisoflavone is the most selective to colon cancer WiDr cell, however the cytotoxic activity of alpinumisoflavone is strong.

Alpinumisoflavone as a major active ingredient commonly used as a traditional Chinese medicine Derris eriocarpa in Southwest part of China possesses a variety of pharmacological activities, including atheroprotective, estrogenic, and anti-bacterial (Wang et al. 2017). Alpinumisoflavone displayed cytotoxicity against the breast cancer MCF-7, lung cancer NCI-H18, and cervical cancer KB cells line with
$\mathrm{IC}_{50}$ values of $>100,>100$, and $4.13 \mu \mathrm{M}$, respectively (Nkengfack et al. 2001; Sudanich et al. 2017). Effects of alpinumisoflavone on proliferation after 24, 48, and $72 \mathrm{~h}$ incubation of human leukemia U937 cell line showed IC ${ }_{50}$ values of 35,32 , and $28 \mu \mathrm{M}$, respectively (Matsuda et al. 2007). Alpinumisoflavone exhibited weak cytotoxic activity against the prostate cancer (PC3) cell line (Iranshahi et al. 2012). Wighteone and alpinumisoflavone isolated from E. indica (Leguminosae) showed cytotoxic activity against KB nasopharyngeal cancer cells, effective doses of 0.78 and $4.13 \mu \mathrm{g} / \mathrm{ml}$, respectively (Orang-ojong et al. 2013).

Alpinumisoflavone is a flavonoid that has a pyran ring as pyranisoflavonoid. Flavonoid pyran groups isolated from medicinal plants that are responsible as active substances. Alpinumisoflavone isolated from E. lysistemon of the African medicinal plant. Alpinumisoflavone reported as a treatment for the prevention of human lung tumor cell death (Namkoong et al. 2011).

Flavonoid substituents shown growth inhibitory activity against cervical cancer (Hela) and colon cancer (WiDr) cells. The presence of hydroxyl group in A-ring in positions 5 also increase the cytotoxic activity of a flavonoids. The presence of hydroxyl group in B-ring in positions $4^{\prime}$ shown increase the cytotoxicity of a flavonoids. B-ring at heterocyclic C3 position instead of $\mathrm{C} 2$ is characteristic of isoflavones. The study of cytotoxic activity of isoflavones showed high activity (López-Lázaro et al. 2002).

\subsection{The Morphological Appearance}

Based on the Figure 1 the morphological appearance of WiDr cell treated with alpinumisoflavone showed the decreasing of cell number, which indicate the effects of treatment toward WiDr cell cells growth. In the Figure 3 and 4, we can see that the morphological appearance of HeLa and $\mathrm{HepG}_{2}$ cells also showed the decreasing of cell number. Its indicate that treatment with alpinumisoflavone influence the cell growth of WiDr, HeLa, and $\mathrm{HepG}_{2}$. The result of present study 
suggests that the alpinumisoflavone might be a promising agent for anticancer treatment.

\section{Conclusion}

Alpinumisoflavone compounds isolated from the stem bark of E. poeppigiana. Alpinumisoflavone showed the highest cytotoxic activity against colon cancer WiDr cell $(5.63 \mu \mathrm{g} / \mathrm{ml})$ compared with hepatoma cancer $\mathrm{HepG}_{2}$ and cervical cancer HeLa cells in vitro by MTT assay method. Alpinumisoflavone has a category of strong cytotoxic activity.

\section{Acknowledgements}

This research was supported by Ministry of Research, Technology and Higher Education, Republic of Indonesia (Hibah Kompetensi, 2018 by TH) through SK no. 1159/UN6.D/LT/2018.

\section{References}

Djiogue S et al. 2009. Isoflavonoids from Erythrina poeppigiana: evaluation of their binding affinity for the estrogen receptor. J Nat Prod 72:1603-1607.

Greenwell M, Rahman PKSM. 2015. Medicinal plants: their use in anticancer treatment. Int J Pharm Sci Res 6:4103-4112.

Herlina T et al. 2017. Isoquinoline alkaloids from Erythrina poeppigiana (Leguminosae) and cytotoxic activity against breast cancer cells line MCF-7 in silico. J Phys: Conf Ser 812 012091. DOI:10.1088/17426596/812/1/012091

Herlina T et al. 2018. Cytotoxic activity of erypogein D from Erythrina poeppigiana (Leguminosae) against cervical cancer (HeLa), breast cancer (MCF-7), and ovarian cancer (SKOV-3) cells. J Phys: Conf Ser 1013012198. DOI:10.1088/1742-6596/1013/1/012198
Hussaini MM et al. 2011. Alpinumisoflavone from Erythrina stricta Roxb. Boletín Latinoamericano y del Caribe de Plantas Medicinales y Aromáticas 10:88-90.

Iranshahi $\mathrm{M}$ et al. 2012. Cytotoxic evaluation of alkaloids and isoflavonoids from the Australian tree Erythrina vespertilio. Planta Med 78:730-736.

López-Lázaro M et al. 2002. Cytotoxicity of flavonoids on cancer cell lines. Structure-activity relationship. Studies in Natural Products Chemistry:891-932.

Matsuda H et al. 2007. Rotenoids and flavonoids with antiinvasion of HT1080, anti-proliferation of U937, and differentiation-inducing activity in HL-60 from Erycibe expansa. Bioorganic and Medicinal Chemistry 15:1539-1546.

Namkoong S et al. 2011. Alpinumisoflavone induces apoptosis and suppresses extracellular signalregulated kinases/mitogen activated protein kinase and nuclear factor- $\kappa \mathrm{B}$ pathways in lung tumor cells. Biol Pharm Bull 34:203-208.

Nkengfack AE et al. 2001. Cytotoxic isoflavones from Erythrina indica. Phytochemistry 58:1113-1120.

Orang-Ojong BB et al. 2013. Impact of natural resources and research on cancer treatment and prevention: a perspective from Cameroon. Mol Clin Oncol 1:610620.

Sudanich S et al. 2017. Cytotoxicity of flavonoids and isoflavonoids from Crotalaria bracteata. Natural Product Research 31:2641-2646.

Tanaka H et al. 2001. Erythrinan Alkaloids and isoflavonoids from Erythrina poeppigiana. Planta Med 67:871-873.

Tanaka H et al. 2002. Isoflavonoids from the roots of Erythrina poeppigiana. Phytochemistry 60:789-794.

Wang T et al. 2017. Alpinumisoflavone suppresses tumour growth and metastasis of clear-cell renal cell carcinoma. Am J Cancer Res 7:999-1015.

Widowati $W$ et al. 2013. Anticancer and free radical scavenging potency of Catharanthus roseus, Dendrophthoe petandra, Piper betle, and Curcuma mangga extracts in breast cancer cell lines. Oxid Antioxid Med Sci 2:137-142. 